\title{
Development and validation of a technology for obstetric intraoperative care safety
}

\author{
Elaboração e validação de tecnologia para segurança do cuidado intraoperatório obstétrico \\ Elaboración y validación de tecnología para la seguridad de la atención intraoperatoria obstétrica
}

'Universidade Federal do Rio de Janeiro. Rio de Janeiro,

Rio de Janeiro, Brazil.

How to cite this article:

Lugão NCS, Brandão MAG, Silva RC. Development and validation of a technology for obstetric intraoperative care safety. Rev Bras Enferm. 2020;73(Suppl 6):e20190605 doi: http://dx.doi.org/10.1590/0034-7167-2019-0605

\section{Corresponding author: \\ Rafael Celestino da Silva \\ E-mail: rafaenfer@yahoo.com.br}

EDITOR IN CHIEF: Dulce Barbosa ASSOCIATE EDITOR: Fátima Helena Espírito Santo

Submission: 08-14-2019

Approval: 06-18-2020

\section{ABSTRACT}

Objectives: to develop and validate an obstetric surgical safety checklist for intraoperative care. Methods: this is a methodological study with two phases: integrative review in databases, using selection criteria and descriptors to synthesize the evidence and develop the checklist; checklist content validation, with 37 judges, who answered a Likert-type questionnaire. For analysis, a > 85\% content validation index was applied. Results: the checklist's first moment reached a 96.1 content validation index; the second moment, 95.5 ; the third moment, 98.9 . Thus, the validation index of all verifying sections present in the three surgical moments was 97.1. Cronbach's Alpha value was $95.57 \%$. Conclusions: the checklist items were validated by judges, with improvement of some items and insertion of others.

Descriptors: Patient Safety; Delivery Rooms; Checklist; Obstetric Surgical Procedures; Patient Care Team.

\section{RESUMO}

Objetivos: elaborar e validar uma lista de verificação de segurança cirúrgica obstétrica para o atendimento intraoperatório. Métodos: estudo metodológico com duas fases: revisão integrativa em bases de dados, com a utilização de critérios de seleção e descritores para a síntese das evidências e construção da lista; validação de conteúdo da lista com 37 juízes, que responderam um questionário utilizando a escala Likert. Para análise, aplicou-se o índice de validação de conteúdo $>85 \%$. Resultados: o primeiro momento da lista alcançou um índice de validação de conteúdo de 96,1 ; o segundo momento, 95,5; o terceiro momento, 98,9. Com isso, o índice de validação de todas as seções de checagem presentes nos três momentos cirúrgicos foi de 97,1. O valor do Alpha de Cronbach foi de 95,57\%. Conclusões: os itens da lista foram validados pelos juízes, com aperfeiçoamento de alguns itens e inserção de outros. Descritores: Segurança do Paciente; Salas de Parto; Lista de Checagem; Procedimentos Cirúrgicos Obstétricos; Equipe de Assistência ao Paciente.

\section{RESUMEN}

Objetivos: desarrollar y validar una lista de verificación de seguridad quirúrgica obstétrica para la atención intraoperatoria. Métodos: estudio metodológico con dos fases: revisión integradora en bases de datos, utilizando criterios de selección y descriptores para sintetizar la evidencia y construir la lista; validación de contenido de la lista con 37 jueces, quienes respondieron un cuestionario utilizando la escala Likert. Para el análisis se aplicó el índice de validación de contenido $>85 \%$. Resultados: el primer momento de la lista alcanzó un índice de validación de contenido de 96,1; el segundo momento, 95,5; el tercer momento, 98,9. Con eso, el índice de validación de todas las secciones de control presentes en los tres momentos quirúrgicos fue de 97,1. El valor Alfa de Cronbach fue del 95,57\%. Conclusiones: los ítems de la lista fueron validados por los jueces, con mejora de algunos ítems e inserción de otros. Descriptores: Seguridad del Paciente; Salas de Parto; Lista de Verificación; Procedimientos Quirúrgicos Obstétricos; Grupo de Atención al Paciente. 


\section{INTRODUCTION}

Improving patient safety is essential for the quality of health care, an aspect that has been the focus of attention by health professionals, institutions and organizations worldwide. In the context of initiatives to improve safety, there is the second global challenge "Safe Surgeries Save Lives", proposed by the World Health Organization (WHO), aiming to reduce mortality from surgeries worldwide ${ }^{(1)}$.

The Surgical Safety Checklist (SSC) was created in 2009 to assist surgical teams in reducing the number of adverse events and defining safety standards that could be applied to all WHO member countries. SSC contains 19 items, divided into three surgery critical moments: before anaesthetic induction, before skin incision, and before patient leaves operating room. SSC is recommended to be applied in all places of health establishments where surgical procedures are performed, with adjustments to each reality ${ }^{(2)}$.

Research results show the positive effects of using SSC, like the research that built a preoperative checklist and concluded that adverse events decreased from $1.5 \%$ to almost $0 \%$, over the time examined ${ }^{(3)}$. Literature review on the effectiveness of SSC also highlighted that, with the use of a checklist, communication failures and active errors could be avoided ${ }^{(4)}$.

At Obstetric Centers (OC), which are the focus of this proposal, there are differences in assistance provided by professionals in relation to the General Surgical Center, as it is a place for assistance to women and newborns; therefore, it implies other steps taken by the team in serving this clientele, which involve handling equipment, including other professionals in teams and specific procedures.

It is noteworthy that the discussion on maternal and child care safety precedes the current perspective of patient safety, since programs have been created over the decades with aiming at giving visibility to women, guaranteeing this public a quality and reduce maternal and neonatal morbidity and mortality. The maternal mortality issue has therefore been a constant concern in concerning obstetric safety, mainly caused by hemorrhage, hypertension, sepsis, abortion, and embolism ${ }^{(5)}$.

Among the most frequent procedures at $O C$ are cesarean section, hysterectomy, and curettage. In Brazil, in 2016, cesarean section was the most performed surgical procedure, followed by uterine curettage ${ }^{(6)}$. A historical series from 1990 to 2013, which involved 18,175 women, revealed a prevalence of cesarean section of $53.03 \%$, higher in the Southeast, South and Center-West regions ${ }^{(7)}$.

However, this procedure involves complications. In the same year of 2016, a total of 106 deaths occurred due to cesarean section and 12 deaths due to curettage (post-abortion/puerperal) (6). Systematic review with meta-analysis indicated moderate evidence that women undergoing cesarean section are more likely to have maternal death and postpartum infection, which points to the need for surgical intervention safety ${ }^{(8)}$.

Hysterectomy, in turn, is one of the most performed gynecological surgeries worldwide, and, particularly, in Brazil, this procedure is also at risk of complications ${ }^{(9)}$. It is also pointed out that pregnancy loss is frequent among Brazilian women, in which a large part of the population needs hospitalization to complete the abortion. A study on the profile of women who underwent uterine emptying revealed that the main diagnosis was incomplete abortion and curettage was the most commonly used final therapy ${ }^{(10)}$.

It is acknowledged that there are already some initiatives in the obstetric field to improve safety, such as the WHO Checklist for Safe Births, released in 2015, which contains essential evidence-based delivery practices; however, it does not include items related to the perioperative period ${ }^{(11)}$.

Moreover, in an exploratory analysis of knowledge production about the object of study, it was found that there is a shortage of publications related to surgical safety at OCs. Such productions, for the most part, depicted changes in the checklist's original version to suit the reality of the institution and were specifically aimed at cesarean sections $s^{(12-13)}$.

This is seen in a study that adapted the WHO SSC for patients undergoing cesarean section, pointing out that, with the use of the checklist, there was an improvement in communication among the surgical team members between patients, in addition to relieving anxiety, tension, and fear ${ }^{(13)}$. On the other hand, uterine curettage, for instance, is one of the most used procedures in obstetrics; although relatively safe, it may be associated with infection, uterine perforation, cervical stenosis, bleeding, and anaesthetic risks ${ }^{(14)}$.

Therefore, it is assumed that developing and validating a checklist focused on the purposes mentioned by experts, Lista de Verificação de Segurança Cirúrgica Obstétrica (LIVESCO - freely translated as Obstetric Surgical Safety Checklist), has the potential to minimize the occurrence of incidents that cause damage to patients, like the devices and fragments retained after surgery, which are a frequent risk. Therefore, the present study is relevant and contributes to obstetric surgical care safety and the performance of nursing professionals at OC.

\section{OBJECTIVES}

To develop and validate an obstetric surgical safety checklist (LIVESCO) for intraoperative care.

\section{METHODS}

\section{Ethical aspects}

The present research was approved by the Research Ethics Committee, under CAAE (Certificado de Apresentação para Apreciação Ética-Certificate of Presentation for Ethical Consideration) 67050017.5.0000.5238 and Opinion 2040036. All participants received, digitally signed and returned their Informed Consent Forms, guaranteeing their anonymity.

\section{Design and period of study}

This is a methodological study conducted in two phases: LIVESCO development and content validation. Phase 1, checklist preparation, was conducted based on an integrative review ${ }^{(15)}$ of scientific articles. Phase 2, LIVESCO validation, took place through 
an online panel of expert judges, using a strategy of combining content validation and reaching consensus. Data collection took place from April to May 2018. GRRAS support was used to present studies of agreement and reliability.

\section{Sample, and inclusion and exclusion criteria}

Phase 1, checklist development, selected scientific articles from the LILACS, MEDLINE, CINAHL, and Scopus databases. These articles addressed items that should appear on the checklist in OC, with the aim of promoting patient safety. The research question was: what items should structure the surgical safety checklist at OC, in order to promote patient safety and reduce adverse event occurrence? "Delivery rooms","checklist", and "patient safety" were the descriptors for searching articles. Specific criteria were applied to select articles through an exploratory reading of titles and abstracts. This phase resulted in the pre-selection of 60 articles, which went through an analytical content reading in full by two researchers, and disagreements were sorted out together. Such procedures indicated the final selection of 11 articles to compose the corpus of analysis.

Phase 2, content validation, recruited nurses and physicians (anaesthetist, obstetrician, or pediatrician) to participate as judges. They were selected according to the following inclusion criteria: having academic experience in obstetrics and/or in patient safety in $\mathrm{OC}$, with current scientific production in these areas; having a graduate degree (lato sensu) in obstetrics and/or graduate degree (stricto sensu) with a focus on obstetrics and/ or patient safety in OC; having practical experience in obstetrics and/or performance in OC for more than 10 years; and/or have practical experience in obstetrics and/or acting in OC for more than 10 years. Professionals whose curriculum update date on the Curriculum Lattes platform was more than two years and who had practical experience in obstetrics and/or acting in OC for more than 10 years, but who were not working at $\mathrm{OC}$ at the time of the research have been excluded.

The minimum sample calculation of experts was done using the formula shown in Figure 1, considering a 95\% confidence level, a $90 \%$ expected proportion of experts and a 10\% acceptable difference (sample error). The aforementioned indicated the need for 35 judges.

$$
\mathrm{n}=\frac{\mathrm{Z}_{1-a / 2} \cdot p \cdot(1-p)}{\mathrm{e}^{2}}
$$

$\mathbf{Z}_{\mathbf{1 - a / 2}}$ refers to the confidence level adopted;

" $\boldsymbol{p}$ " refers to the expected proportion of experts, showing the adequacy of each item;

"e" represents the difference of acceptable proportion in relation to what would be expected.

Source: Lopes MV, Silva VM, Araújo TL. Research methods for clinical validation of diagnostic concepts. In: NANDA International Inc; Herdman TH, Carvalho EC, organizers. PRONANDA Nursing Diagnostics Update Program - Basic Concepts. Porto Alegre: Artmed; 2013. p.85-129.

Figure 1 - Statistical formula for sample calculation of the study

After defining the minimum sample, judges were recruited in two ways: the first, through their Curriculum Lattes resumes; the second, through participation in research groups in CNPq's
"Directory of Research Groups". Identification occurred using the search keywords on such platforms. Subsequently, contact was made individually, directing the invitation, explaining the reason why the participant was selected and presenting the question focus of the investigation. The second mode of recruitment was through the Snowball technique. Participants identified in the previous phase were asked to assign other professionals who specialize in the research thematic fields and their contact email, in order to recruit potential professionals with practical experience to participate in the research.

The participants' data identified in the two stages were arranged in a spreadsheet, totaling the initial number of 160 potential participants. Of these, 49 responded to the researcher's contact email and 37 completed the data collection step within 30 days. Therefore, the final sample consisted of 37 judges in the validation phase.

\section{Study protocol}

In the integrative review, an instrument structured in the following sections was used to collect data: type of publication and place of study, objectives, methodological characteristics, level of evidence, results, limitations, and recommendations. After collecting this information, the data were organized into a synthesis chart from which article content was analyzed. In this regard, an interpretative reading of such content was made, looking for elements that answered the research question, which, after understood, were synthesized in two categorical units of evidence: 1 - positive effects of using the checklist; 2 - checklist adherence by professionals and associated factors.

The first unit of evidence included six articles, which pointed out the positive effects for patients and health teams with LIVESCO implementation. Concerning health teams, the studies reported, mainly, the improvement in surgical team communication and failure reduction. In relation to patients, there were benefits, such as decreased hospitalizations and readmissions, infections and complications and level of anxiety. The second unit of evidence was constructed based on five articles, which indicated the checklist items of greatest adherence, as is the case of items that threaten life and confirm evidence-based practices, and the factors that interfere with professional adherence, such as surgery with a longer duration and in older patients, previous training, team collaboration/cooperation.

Such units provided the necessary evidence to develop six checklist sections: 1 - patient data verification; 2 - patient preparation data verification; 3 - procedure data verification before performance; 4 - verifying equipment and devices; 5 - prophylaxis verification; 6 - checklist completion. Subsequently, the sections were organized according to the following moments: before anaesthetic induction; before surgical incision; before leaving operating room. Section 1 would be exclusive to the moment before anaesthetic induction; section 5 was not included just before leaving operating room; section 6 was intended exclusively for before leaving operating room.

The prototype of LIVESCO's first version was built by the main researchers from the results of the articles included in the integrative review. This prototype was structured based on the three 
moments of the WHO's SSC model (before anaesthetic induction, before surgical incision, before patient leaves operating room). The items gathered from the review were initially distributed according to the verification sections present in these three moments. Subsequently, the number of times that each item was identified in the set of studies analyzed was counted, to highlight the items that obtained the greatest amount of appearance. Next, there was a qualitative analysis of item relevance in relation to the objective of promoting obstetric safety. After this analysis, the researchers decided on the items that would compose LIVESCO's first version submitted for validation.

For validation, an electronic form questionnaire created in Google Docs ${ }^{\circ}$ was constructed. The first part addressed participant characterization, and the second part incorporated the statements related to the content of LIVESCO items, verifying the judges' opinion about relevance, conciseness, accuracy, pertinence, and clarity. The statements were judged using the Likert scale (1 Disagree, 2 - Partially Disagree, 3 - Partially Agree and 4 - Agree). The participants should express their opinion with the choice of one of these statements, filling the space for justification when answering options 1, 2 and 3 .

\section{Analysis of results, and statistics}

In order to understand the evidence in the integrative review phase, an interpretative reading of article content was performed aiming to establish the links of the research results with the phenomenon under investigation. This analytical procedure made it possible to construct the units of evidence and, later, to survey the verification sections items.

Phase 2, validation, applied descriptive statistics to participants characterization data with simple and percentage frequencies. To quantify the agreement degree among judges, the Content Validity Index (CVI) was used, in which the index score was calculated by adding the agreement of items that were marked by " 3 " (partially agree) or "4" (agree) by experts (valid answers), multiplied by 100 .

In content-related data analysis, the items were validated if they obtained a CVI greater than or equal to $85 \%$. For the items considered valid and for the items excluded, thematic grouping and quantification of the participants'justifications for those receiving score 1, 2 or 3 and subsequent exhaustive reading were made to understand why there was item disagreement or partial agreement. This procedure promoted content adjustment of the validated items and understanding the reasons for rejection of those excluded.

The R software was used in the Cronbach's Alpha test to measure internal consistency (extension in which the items measure the same concept or construct), considering a 0.8 minimum value; and Fleiss's Kappa calculation, to describe agreement among judges, whose values range from - 1 (total absence of agreement) to 1 (total agreement).

\section{RESULTS}

Of a total of 37 judges, in relation to sex, 27 were female and 10 were male. The predominant age range was between 35 and 44 years (48.7\%), followed by age between 45 and 59 years (35.1\%). The investigated group had 26 nurses $(70.3 \%)$ and 11 physicians (29.7\%). Of the physicians, 9 (81.8\%) were experts in gynecology and obstetrics and 2 (18.2\%) were experts in anaesthesia.

Most study participants were from the state of Rio de Janeiro, with 25 participants (67.6\%). Concerning job tenure, $11(29.8 \%)$ participants reported having between 20 and 29 years of training and 20 (54\%) between 10 and 19 years. Thirty-two were healthcare professionals, of which 17 (46.0\%) worked concomitantly in care and as professors and/or researcher and 15 (40.5\%) exclusively in obstetric care. Five participants (13.5\%) worked exclusively in teaching and/or research.

Concerning taking part in research groups/projects on the theme, 16 participants worked in groups/projects, of which 15 were from obstetrics. Only one participant claimed to be part of a patient safety group/project at OC. A percentage of 21 (56.8\%) participants stated that they had scientific production (scientific article and books) in this thematic area.

As for header content assessment, the CVI for all the criteria assessed (relevance, conciseness, accuracy, pertinence, and clarity) as well as total CVI was maximum (100). The CVI of the sections according to the checklist time is shown in Table 1.

The Cronbach's Alpha value computed in the R software was $95.57 \%$ and the Fleiss Kappa value was 0.29. Based on the judges' recommendations and on scientific literature analysis, some items were included, adapted and excluded, producing LIVESCO's final version, shown in Figure 2.

Table 1 - Content Validity Indexes of the verification sections, depending on the moment of assessment at Lista de Verificação de Segurança Cirúrgica Obstétrica (Obstetric Surgical Safety Checklist), Rio de Janeiro, Rio de Janeiro, Brazil, 2018

\begin{tabular}{|c|c|c|c|c|c|c|c|c|c|c|c|c|c|}
\hline \multirow{3}{*}{$\begin{array}{l}\text { Moment } \\
\text { Sections }\end{array}$} & \multicolumn{13}{|c|}{ LIVESCO's Content Validity Index at the time of assessment } \\
\hline & \multicolumn{5}{|c|}{ Before anaesthetic induction } & \multicolumn{4}{|c|}{ Before surgical incision } & \multicolumn{4}{|c|}{ Before leaving operating room } \\
\hline & $1 *$ & 2 & 3 & 4 & 5 & 2 & 3 & 4 & 5 & 2 & 3 & 4 & 6* \\
\hline \multicolumn{14}{|l|}{ Criteria } \\
\hline Relevance & 100 & 97.3 & 100 & 100 & 78.4 & 94.6 & 94.6 & 97.3 & 97.3 & 100 & 100 & 97.3 & 100 \\
\hline Conciseness & 97.3 & 97.3 & 97.3 & 100 & 94.6 & 94.6 & 91.9 & 94.6 & 94.6 & 97.3 & 94.6 & 100 & 100 \\
\hline Precision & 97.3 & 100 & 97.3 & 97.3 & 89.2 & 97.3 & 94.6 & 97.3 & 97.3 & 100 & 97.3 & 100 & 100 \\
\hline Relevance & 100 & 97.3 & 100 & 97.3 & 75.7 & 94.6 & 91.9 & 97.3 & 91.9 & 100 & 97.3 & 100 & 97.3 \\
\hline Clarity & 97.3 & 100 & 100 & 100 & 94.6 & 97.3 & 94.6 & 97.3 & 100 & 100 & 97.3 & 100 & 100 \\
\hline Section's total CVI & 98.4 & 98.4 & 98.4 & 98.9 & 86.5 & 95.7 & 93.5 & 96.8 & 96.2 & 99.5 & 96.8 & 100 & 99.5 \\
\hline Moment's total CVI & \multicolumn{5}{|c|}{96.1} & \multicolumn{4}{|c|}{95.5} & \multicolumn{4}{|c|}{98.9} \\
\hline
\end{tabular}

Note: LIVESCO - Lista de Verificação de Segurança Cirúrgica Obstétrica (Obstetric Surgical Safety Checklist); *Section contained exclusively at the time of assessment; CVI - Content Validation Index. Source: researcher's production, 2018. 


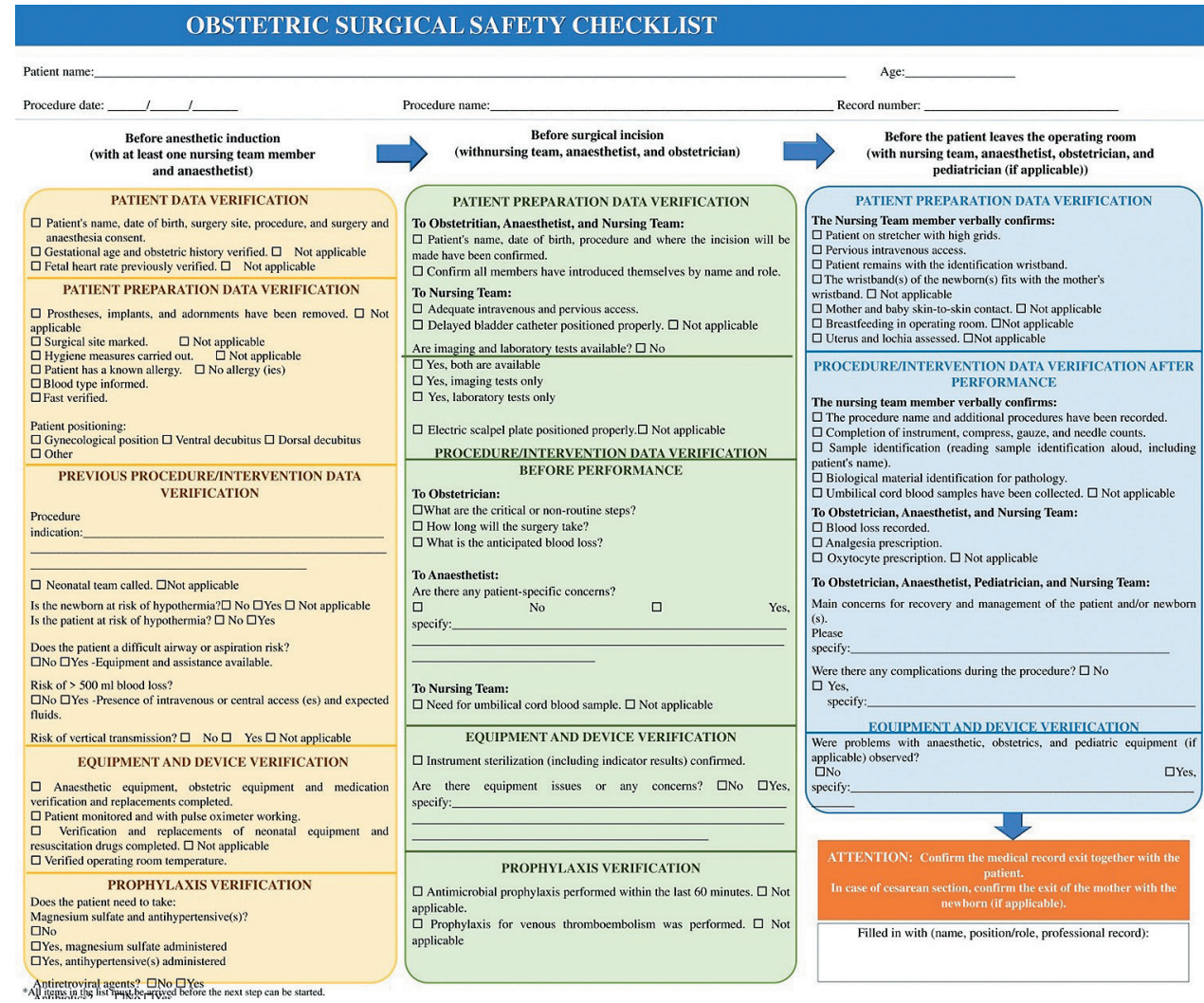

Note: LIVESCO has not been validated and translated into English, so a free translation was made for the understanding of the international public. Figure 2 - Lista de Verificação de Segurança Cirúrgica Obstétrica (Obstetric Surgical Safety Checklist)'s final version

\section{DISCUSSION}

Concerning analysis of LIVESCO validation, it was found that, in the first moment, only section 5 obtained a lower CVI than expected in the relevance and relevance criteria. However, in the other criteria, CVI exceeded the minimum value, making this section validated, as well as the first moment.

It is also evident that all the verifying sections of the second stage obtained an CVI higher than 85.0, which allowed us to conclude that these sections were validated. This, in turn, also applies to the third moment, which obtained the highest CVI value among the three moments. Concerning the Cronbach's alpha test, the result obtained was almost perfect, while Fleiss' Kappa indicated a median agreement, which can be attributed to the sample of research judges, which was different in relation to the professional category, place, and practice field.

The results obtained from LIVESCO's final version are compared with other proposals for a safety checklist aimed at obstetric scenarios, identified in the literature, in order to point out the similarities, differences, and particularities. One of these proposals is presented in clinical practice guidelines, in which the authors state that using a modified and adapted checklist for obstetric and gynecological surgeries is a recommendation with good evidence to guarantee women's health and well-being. Its use allows observing maternal and neonatal factors as well as allowing the team to prepare for surgical difficulties and for newborn care and resuscitation ${ }^{(16)}$.

In this guideline, the authors presented an obstetric checklist used in Canadian hospitals ${ }^{(16)}$. Among the similarities with LIVESCO validated in this article, the following items stand out: fetal state verification, neonatal support team, hypothermia risk and venous thromboembolism prophylaxis.

In relation to these items, fetal vitality verification, found in section 1 of the first moment of LIVESCO, should be verified by assessing the rhythm, frequency and abnormality of the fetal heart rate. In addition to this assessment, verifying gestational age and obstetric antecedents was added, in order to know the patients' profile and safely guide their care ${ }^{(17)}$.

As for the importance of the item that addresses neonatal team presence in the verification section 3 , which refers to the procedure/intervention to be performed, verifying neonatal team presence in operating room in the event of a cesarean section is necessary for newborn care. A pediatrician trained presence in neonatal resuscitation is recommended. If this is not possible, a medical or nursing professional who has been trained presence in neonatal resuscitation is required ${ }^{(18)}$.

Concerning hypothermia, newborn temperature should also be a concern by surgical team, because babies are particularly sensitive to the cold and complications can quickly arise if the body temperature drops below the normal limit ${ }^{(19)}$. This time, concern with hypothermia risk must be considered in woman and newborn care, with passive and active measures to prevent hypothermia during surgery, such as adjusting the operating room temperature.

Prophylaxis verification for venous thromboembolism was added to LIVESCO, as pregnancy is a period in which anatomical and hormonal changes occur in women. Thus, venous thromboembolism risk increases five to ten times, increasing (up to 20 times) in the puerperium, when compared to that of non-pregnant women ${ }^{(20)}$. A fact that constitutes a warning to professionals in terms of prophylaxis and treatment is that women undergoing cesarean section have a higher risk of developing venous thromboembolism than those who perform spontaneous vaginal delivery. Therefore, the health team must be aware of the need to administer prophylaxis for venous thromboembolism ${ }^{(21)}$.

Another validated checklist that can be compared with the results of this investigation is the surgical safety checklist in cesarean section. Concerning instrument validation, the overall CVI obtained from the judges' assessment was 0.9 , and Cronbach's Alpha, 0.86 . It became evident that verifying chemoprophylaxis against HIV and identifying the mother and newborn were obstetric items similar to those present in LIVESCO $^{(22)}$. 
It is pointed out that mother-baby correct identification, present in the verification section 2 , is due to the fact that risk of errors in identifying patients is a reality, as indicated by research developed in the public maternity obstetric unit to determine the frequency of similar hospital names and records as well as risk of errors in identification. Of the 5,975 admissions that occurred between 2011 and 2014, analysis of similarities showed $86 \%$ of identical spellings of surname and $96.5 \%$ of similarity in the sound of the first name. On at least one day of the week, there were women with identical first and last names ${ }^{(23)}$.

In the US, at least 1,000 newborns are mistakenly exchanged and sent to the wrong home each year ${ }^{(24)}$. Another example of this exchange is found in a study carried out in a Federal District hospital, which found near miss occurrence, in which a wrong patient was called for one of the cesarean sections; however, the incident was corrected by a team professional ${ }^{(25)}$. Therefore, verifying woman and newborn identification is an important aspect.

Also included in the adequacy of LIVESCO is a verification item called "Risk of vertical transmission", as infections acquired during childbirth and intrauterine infections can damage the health of newborns and are causes of fetal and neonatal mortality ${ }^{(26)}$. A study carried out in southern Brazil on the prevalence of diseases with possible vertical transmission concluded that syphilis and HIV infections figured prominently in pregnant women, higher than the national average, and women who sought less prenatal care were more vulnerable to infections ${ }^{(27)}$.

This result is congruent with a second study, in which HIV prevalence during pregnancy in Brazil was estimated, based on a survey of 23,894 women. Among the women who presented the prenatal card, there was an $81.7 \%$ HIV testing coverage, and HIV prevalence was $0.4 \%$, more frequent in black, southern women, with less than eight years of education and coinfected by syphilis ${ }^{(28)}$. Considering these aspects, verifying antiretroviral administration was added to LIVESCO's final version.

Among the checklists selected for further discussion is the WHO safe delivery checklist, adapted and validated for Brazil. This is a checklist for situations of normal delivery, divided into three moments: on parturient admission, before, and after the fetus expulsion. The final version contains 49 items present in the three moments of this checklist, among which verifying magnesium sulfate use and the need for antihypertensive ${ }^{(11)}$.

In the case of LIVESCO, after the judge assessment round, it was suggested to include an item in the prophylaxis verification section for magnesium sulfate. This medication is used in the prophylactic treatment of mothers with pre-eclampsia and is complemented with the use of an antihypertensive, in order to avoid complications such as postpartum hemorrhage ${ }^{(29)}$.

Hypertensive syndromes in pregnancy are one of the main causes of maternal death, which can be seen in a survey of maternal deaths that occurred from 2000 to 2012 in a hospital in São Paulo, during which 58 maternal deaths occurred. In analysis of these deaths, $56.9 \%$ of women underwent cesarean section, $81 \%$ of deaths occurred in the puerperium and $44.8 \%$ due to hypertension ${ }^{(30)}$. In the prophylaxis verification section, the judges suggested removing the antacid verification item, which obtained the least agreement on the checklist, which was accepted by the researchers after analyzing the scientific literature, due to the lack of reasoning to support its maintenance.

Items that constituted particularities of LIVESCO, proposed considering obstetric care safety, were collection of umbilical cord blood, oxytocyte prescription, indication of cesarean section and bladder catheter verification. Umbilical cord blood collection aims to collect hematopoietic stem cells for umbilical cord blood banks. If the pregnant woman authorizes it, collection must be performed during the third stage of cesarean section ${ }^{(31)}$.

An alert regarding the need to collect umbilical cord blood leads the surgical team to prepare the necessary materials for collection, preventing eventual forgetfulness. It is considered good practice that there is a signal from a potential donor and communication to the obstetric team about extrauterine collection after placental delivery ${ }^{(32)}$.

Verifying "oxytocyte prescription" aims at prophylaxis of postpartum hemorrhage, an item that was validated by the judges for its relevance. Blood loss and postpartum hemorrhage risks during an obstetric surgical procedure should be a concern present in the daily routine of professionals working in obstetric centers, since postpartum hemorrhage is one of the main causes of maternal death. This statement can be supported by the results of a research that analyzed maternal mortality ratio due to hemorrhage identified in Brazil, from 1997 to 2009, through population data. Of the 22,281 deaths in women aged 10 to 49 years, 3,174 were due to hemorrhage, equivalent to $14.26 \%$. Postpartum hemorrhage with $41 \%$ and placental abruption with $30 \%$ were the two main causes of deaths from hemorrhage ${ }^{(33)}$. Oxytocin is a uterotonic drug recommended to prevent hemorrhage in cesarean deliveries ${ }^{(34)}$.

In the final version, it was decided to insert a place to describe the indication of the procedure to be performed. In a study to assess whether a checklist use reduced the differences in classification between obstetricians, cesarean section indication was considered essential information that should be verified and recorded before performing this procedure. The authors categorized cesarean sections into grades: Grade 1: immediate threat to the lives of women or fetuses; Grade 2: maternal or fetal impairment that is not immediately fatal; Grade 3: no maternal or fetal impairment, but needs an early delivery; Grade 4: delivery scheduled to attend women or team ${ }^{(35)}$.

With the mandatory filling of this item in the checklist, there was a reduction in the differences in indication and classification between anaesthetists and obstetricians regarding surgical procedure, improvement in interprofessional communication, with reduction of communication failures ${ }^{(35)}$.

Finally, in relation to bladder catheter placement, in the case of hysterectomy, for instance, urine output control is necessary in operating room and for anaesthetic recovery, as the cut performed by obstetricians comes close to the bladder and its attachments, that brings risk of injury ${ }^{(36)}$. The systematic review with meta-analysis $(n=40,606)$ estimated the incidence of lesions in the ureter and bladder to be $0.3 \%$ and $0.8 \%$ during hysterectomy ${ }^{(37)}$.

Based on LIVESCO content validation, it is appropriate to discuss the limits and possibilities of its applicability in obstetric care and its impact on patient safety. In the theoretical perspective 
of safety, it is necessary to prevent error occurrence or mitigate its consequences when it happens, seeking to understand the multiple factors related to it, i.e., analysis of human errors must be systemic. Systemic thinking shows that when there are no layers of defense, barriers analogous to Swiss cheese, the holes in the cheese communicate and the risk reaches patients, causing the accident $^{(38)}$. In this understanding, it is necessary to invest in the creation of barriers in OC, in order to prevent error occurrence, as is the case of LIVESCO.

Among the benefits of checklists such as LIVESCO, several studies have suggested an increase in quality of care ${ }^{(12-13,39)}$. One investigated patients' perception on the implementation of the WHO surgical safety checklist, adapted for patients undergoing cesarean section under regional anaesthesia agreed in Japan. Participants pointed out that there was an improvement in communication among team members surgical and safety awareness after using a checklist. There was also an improvement in communication between patients and the team, with the potential to positively impact the trust relationship between both ${ }^{(39)}$.

On the other hand, one of the limits of LIVESCO is adherence and knowledge by professionals. A study carried out in Ethiopia assessed the adherence of a checklist used for obstetric procedures and identified the challenges and barriers for its use. The overall compliance rate was suboptimal, as the checklist was completed in only $39.7 \%(112 / 282)$ of the operations carried out. The main reasons cited for not using the checklist were the lack of prior training and non-cooperative surgical teams ${ }^{(40)}$.

However, there was satisfactory adherence in filling out the list items (63.4\%). Checklists were used most often during the day, in emergency patients, who underwent general anaesthesia. The section referring to leaving operating room (sign-out) was seen as more difficult and was completed in only $54.3 \%$ of surgeries ${ }^{(40)}$.
Therefore, facing the potential challenges in the applicability of LIVESCO goes beyond the awareness of managers about its importance in promoting a safety culture in obstetric care, investments in training teams and actions that envisage adherence to use this technology to improve quality assistance provided.

\section{Study limitations}

The limitations are methodological and related to the difficulty of recruiting participants online. This resulted in the number of participants and the fact that it was not possible to reach the opinion of judges from all Brazilian states. Furthermore, most of the judges recruited were from the Southeast.

\section{Contributions to nursing and health}

It is hoped that LIVESCO can be used by health units as an instrument to strengthen surgery safety, assisting teams in providing patient care. Furthermore, the applicability of LIVESCO in surgical practice has the potential to impact adverse event reduction, which requires further studies.

\section{CONCLUSIONS}

The content validation performed by LIVESCO's judges generated a specific checklist for obstetrics, with item clarity, precision, conciseness, pertinence, and relevance, which made it possible to reach the outlined objective. Therefore, the proposed instrument should be applied in care practice by OC professionals, assessing its suitability for different realities and the need for inclusion/exclusion of items, as well as its effect on the safety of professionals performance in procedures surgical procedures, particularly nurses.

\section{REFERENCES}

1. World Health Organization. World Alliance for patients safety. The second global patient safety challenge: safe surgery saves lives. Genebra; 2008 .

2. Torres-Manrique B, Nolasco-Bonmati A, Maciá-Soler L, Milberg M, Vilca AN, López-Montesinos MJ, et al. Cultural analysis of surgical safety checklist items in Spain and Argentina. Rev Gaúcha Enferm [Internet]. 2016 [cited 2017 Nov 07];37(1):e56359. Available from: https://seer. ufrgs.br/RevistaGauchadeEnfermagem/article/view/56359/38096

3. Harris AM, Preece K, Harris, C. Using a STOP/GO protocol in the preoperative area to increase patient safety. J Periop Pract [Internet]. 2016 [cited 2018 Aug 05];26(10):229-31. Available from: https://journals.sagepub.com/doi/abs/10.1177/175045891602601004

4. Collins SJ, Newhouse R, Porter J, Talsma A. Effectiveness of the surgical safety checklist in correcting errors: a literature review applying Reason's Swiss cheese model. AORN J [Internet]. 2014 [cited 2018 Aug 01];100(1):65-79. Available from: https://aornjournal.onlinelibrary. wiley.com/doi/abs/10.1016/j.aorn.2013.07.024

5. Say L, Chou D, Gemmill A, Tunçalp Ö, Moller AB, Daniels J, et al. Global causes of maternal death: a WHO systematic analysis. Lancet Glob Health. 2014;2(6):e323-33. doi: 10.1016/S2214-109X(14)70227-X 2

6. Ministério da Saúde (BR) Datasus. Sistema de Informações Hospitalares do SUS (SIH/SUS). 2018[cited 2018 Aug 05]. Available from: htpp:// tabnet.datasus.gov.br/cgi/tabcgi.exe?sim/cnv/mat10of.def

7. Eufrásio LS, Souza DE, Fonsêca AMC, Viana ESR. Brazilian regional differences and factors associated with the prevalence of cesarean sections. Fisioter Mov [Internet]. 2018 [cited 2018 Aug 01];31:e003108. Available from: http://www.scielo.br/pdf/fm/v31/1980-5918-fm-31-e003108.pdf

8. Mascarello KC, Horta BL, Silveira MF. Maternal complications and cesarean section without indication: systematic review and metaanalysis. Rev Saúde Pública [Internet]. 2017 [cited 2018 Aug 01];51:105. Available from: http://www.scielo.br/pdf/rsp/v51/0034-8910rsp-S1518-87872017051000389.pdf

9. Freitas CB, Gomes NP, Campos LM, Estrela FM, Cordeiro KCC, Santos RM. Complicações pós-cirúrgicas da histerectomia: revisão integrativa. Rev Baiana Enferm. 2016;30(2):1-11. doi: 10.18471/rbe.v30i2.15660 
10. Araújo CP, Dornelas ACVR, Sousa AM. Therapeutic approach in the uterine evacuation process. Rev Baiana Enferm. 2018;32:e24857. doi: $10.18471 /$ rbe.v32.24857

11. Carvalho ICBM, Freitas MR, Medeiros WR, Moutinho NF, Pimenta IDSF, Gama ZAS. Adaptation and validation of the World Health Organization's Safe Childbirth Checklist for the Brazilian context. Rev Bras Saude Matern Infant [Internet]. 2018 [cited 2018 Nov 10];18(2):401-18.Available from: http://www.scielo.br/pdf/rbsmi/v18n2/1519-3829-rbsmi-18-02-0401.pdf

12. Kawano T, Tani M, Taniwaki M, Ogata K, Yokoyama M. A preliminary study of patients' perceptions on the implementation of the WHO surgical safety checklist in women who had Cesarean sections. J Anesth [Internet]. 2015 [cited 2017 Oct 27];29(3):459-62. Available from: https://link.springer.com/article/10.1007\%2Fs00540-014-1934-3

13. Kim RY, Kwakye G, Kwok AC, Baltaga R, Ciobanu G, Merry AF, et al. Sustainability and long-term effectiveness of the WHO surgical safety checklist combined with pulse oximetry in a resource-limited setting: two-year up date from. JAMA Surg [Internet]. 2015 [cited 2017 Oct 27];150(5):473-9. Available from: https://jamanetwork.com/journals/jamasurgery/fullarticle/2207940

14. Arcanjo FCN, Ribeiro AS, Teles TG, Macena RHM, Carvalho FHC. Uso do misoprostol em substituição à curetagem uterina em gestações interrompidas precocemente. Rev Bras Ginecol Obstet [Internet]. 2011 [cited 2018 Aug 01];33(4):276-80. Available from: http://www.scielo. $\mathrm{br} / \mathrm{pdf} / \mathrm{rbgo/v33n6/a03v33n6.pdf}$

15. Soares CB, Hoga LAK, Peduzzi M, Sangaleti C, Yonekura T, Silva DRAD. Integrative review: concepts and methods used in nursing. Rev Esc Enferm USP [Internet]. 2014 [cited 2016 Oct 02];48(2):335-45. Available from: http://www.scielo.br/pdf/reeusp/v48n2/0080-6234-reeusp-48-02-335.pdf

16. Singh SS, Mehra N, Hopkins L. Surgical safety checklist in obstetrics and gynaecology. J Obstet Gynaecol Can. 2018;40(3):e237-e242. doi: 10.1016/j.jogc.2018.01.018

17. Organização Mundial da Saúde (OMS). Assistência ao parto normal: um guia prático. Relatório de um grupo técnico. Genebra: OMS; 1996.

18. Ministério da Saúde (BR). Secretaria de Atenção à Saúde. Portaria n 306, de 28 de março de 2016. Diretrizes de Atenção à Gestante: a operação cesariana [Internet]. Brasília; 2016 [cited 2018 Jul 03]. Available from: http://portalarquivos2.saude.gov.br/images/pdf/2016/ marco/31/MINUTA-de-Portaria-SAS-Cesariana-03-03-2016.pdf

19. Carpenter L, Baysinger CL. Maintaining perioperative normothermia in the patient undergoing cesarean delivery. Obstet Gynecol Surv. 2012;67(7):436-46. doi: 10.1097/OGX.0b013e3182605ccd

20. Evangelista MS, Slompo K, TimiJRR.Venous Thromboembolism and route of delivery - review of the literature. Rev Bras Ginecol Obstet [Internet]. 2018 [cited 2018 Aug 01];40(3):156-162. Available from: http://www.scielo.br/pdf/rbgo/v40n3/0100-7203-rbgo-40-03-00156.pdf

21. Fernandes BB, Nunes FBBF, Prudêncio PS, Mamede FV. Epidemiological research of the maternal deaths and compliance with the fifth millennium development goal. Rev Gaúcha Enferm. 2015;36(spe):192-9. doi: 10.1590/1983- 1447.2015.esp.56792

22. Boeckmann LMM, Rodrigues MCS. Adaptation and validation of a surgical safety checklist in the cesarean delivery. Texto Contexto Enferm. 2018;27(3):e2780017. doi: 10.1590/0104-070720180002780017

23. Tase TH, Quadrado ERS, Tronchin DMR. Evaluation of the risk of misidentification of women in a public maternity hospital. Rev Bras Enferm. 2018;71(1):120-5. doi: 10.1590/0034-7167-2017-0134

24. Tiwari S, Singh A, Singh SK. Multimodal database of new borns for biometric recognition, IJBSBT [Internet]. 2013 [cited 2017 Mar 12];5(2):89100. Available from: https://www.ijbsbt.com

25. Boeckmann LMM, Rodrigues MCS. Surgical safety in cesarean section: integrative review. Cogitare Enferm [Internet]. 2015 [cited 2017 Oct 27];20(4):752-60. Available from: https://revistas.ufpr.br/cogitare/article/view/41089/26745

26. Yeganeh N, WattsHD, Camarca M, Soares G, Joao E, Pilotto JH et al. Syphilis in HIV-infected mothers and infants: results from the NICHD/ HPTN 040 study. Pediatr Infect Dis J. 2015;34(3):e52-7. doi: 10.1097/INF.00000000000000578

27. Gonçalves C, Peres AC, Zatt D, Zanella N, Schneider E, Daros P. Prevalência de infecções de possível transmissão vertical em gestantes de um Hospital Universitário no Sul do Brasil. Medicina. 2016;49(6):526-32. doi: 10.11606/issn.2176-7262.v49i6p526-532

28. Domingues RMSM, Szwarcwald CL, Souza Jr PRB, Leal MC. Prenatal testing and prevalence of HIV infection during pregnancy: data from the "Birth in Brazil study, a national hospital-based study. BMC Infec Dis. 2015;15:100. doi: 10.1186/s12879-015-0837-8

29. Herrera JA, Medina RH, Escobar JPH, Díaz AN. Reduction of maternal mortality due to preeclampsia in Colombia-an interrupted time-series analysis. Colomb Med [Internet]. 2014 [cited 2018 Nov 20];45(1):25-31. Available from: http://www.scielo.org.co/pdf/cm/v45n1/v45n1a04.pdf

30. Simcox LE, Ormesher L, Tower C, Greer IA. Pulmonary thromboembolism in pregnancy: diagnosis and management. Breathe [Internet]. 2015[cited 2018 Aug 01];11(4):282-9. Available from: https://www.ncbi.nlm.nih.gov/pmc/articles/PMC4818214/

31. Roura S, Pujal JM, Monton CG, Genis AB. The role and potential of umbilical cord blood in an era of new therapies: a review. Stem Cell Res Ther [Internet]. 2015 [cited 2018 Jul 03];6(1):123. Available from: http://www.stemcellres.com/content/pdf/s13287-015- 0113-2.pdf

32. Lopes LA, Bernardino E, Crozeta K, Guimarães PRB. Good practices in collecting umbilical cord and placental blood. Rev Latino-Am Enfermagem [Internet]. 2016 [cited 2018 Aug 01];24:e2770. Available from: http://www.scielo.br/pdf/rlae/v24/0104-1169-rlae-24-02770.pdf

33. Souza ML, Laurenti R, Knobel R, Monticelli M, Brüggemann OM, Drake E. Maternal mortality due to hemorrhage in Brazil. Rev Latino-Am Enfermagem. 2013;21(3):711-8. doi: 10.1590/S0104-11692013000300009

34. Yamaguchi ET, Siaulys MM, Torres MLA. Oxytocin in cesarean-sections. What's new? Rev Bras Anestesiol [Internet]. 2016 [cited 2018 Dec 02];66(4):402-7 Available from: http://www.scielo.br/pdf/rba/v66n4/0034-7094-rba-66-04-0402.pdf 
35. Mohammed A, Wu J, Biggs T, Ofili-Yebovi D, Cox M, Pacquette S, et al. Does use of a World Health Organization obstetric safe surgery checklist improve communication between obstetricians and anaesthetists? a retrospective study of 389 caesarean sections. BJOG [Internet]. 2013[cited 2017 Oct 27];120(5):644-8. Available from: https://obgyn.onlinelibrary.wiley.com/doi/abs/10.1111/1471-0528.12041

36. Le Gouez A, Bonnet M-P. Anestesia para cesárea. EMC - Anest Reanim [Internet]. 2016; 42(1):1-11. doi:10.1016/s1280-4703(15)76022-6

37. Teeluckdharry B, Gilmour D, Flowerdew G. Urinary tract injury at benign gynecologic surgery and the role of cystoscopy: a systematic review and meta-analysis. Obstet Gynecol [Internet]. 2015 [cited 2018 Aug 01];126(6):1161-9. Available from: https://www.ncbi.nlm.nih.gov/ pubmed/26551173

38. Reason J. Human errors: models and management. BMJ;2000;320:768-70

39. Melekie TB, Getahun GM. Compliance with surgical safety checklist completion in the operating room of University of Gondar Hospital, North West Ethiopia. BMC Res Notes. 2015;8:361. doi: 10.1186/s13104-015-1338-y

40. Kawano T, Tani M, Taniwaki M, Ogata K, Yokoyama M. A preliminary study of patients' perceptions on the implementation of the WHO surgical safety checklist in women who had Cesarean sections. J Anesth. 2015; 29(3):459-462. doi: 10.1007/s00540-014-1934-3 